\title{
Altering nutrient utilization in animals through transgenesis
}

\author{
Kevin A. Ward \\ Commonwealth Scientific and Industrial Research Organization (CSIRO) Animal Production, \\ Locked Bag 1, Delivery Center, Blacktown, NSW 2148, Australia
}

\begin{abstract}
Improved domestic animal productivity is necessary in order to provide for an increasing world population over the next two to three decades and such improvement would be aided by an increase in the efficiency of nutrient utilization. This can be achieved by conventional genetic selection protocols but progress by this approach is slow. A more rapid but as yet largely unproven technique is the direct modification of the genome which can be achieved by the transfer of recombinant DNA to the nuclei of early embryos. This new technology is potentially powerful because it allows the direct transfer of genes without regard to inter-species barriers to breeding. However, it raises a new set of problems associated with the integration and expression of the foreign genetic information in the new genome. In this review the application of the technology to increasing nutrient utilization and increased productivity are discussed. Two areas have received substantial attention in the 15 years since the technique was first applied to domestic animals. First, the current status of the modification of growth hormone levels to improve productivity and feed utilization efficiency is reviewed, with current results suggesting that several of the projects may soon be approaching field trial status. Second, the introduction of novel biochemical pathways to domestic animals to provide them with different sources of the substrates required for growth and production is discussed. Recent results obtained in the introduction of a cysteine biosynthetic pathway to animals is reviewed. While this line of research remains some distance from commercial application, it provides a useful example of the powerful possibilities inherent in the new technology. However, it also serves to highlight some of the difficulties that might be expected as new genes are expressed to produce enzymes that must fit compatibly with existing animal biochemistry.
\end{abstract}

Transgenics : Nutrient utilization

\section{Introduction}

Domestic animal production is important to the immediate and long-term future of the human condition, providing as it does vital supplies of food and other products. It is therefore of some

\footnotetext{
Abbreviations: GH, growth hormone; IGF-1, insulin-like growth factor-1; MT, metallothionein; OAS, $O$-acetylserine sulfhydrase; SAT, serine transacetylase.

Corresponding author: Dr Kevin A. Ward, fax +61 298 402940, email kevin@nugget.prospect.anprod.csiro.au
} 
concern that the resources needed to support current levels of production are becoming increasingly strained by a burgeoning human population and a limited global carrying capacity. If current trends continue, a crisis in animal production appears inevitable (Brown, 1997), and our options for alleviating it are limited. The most attractive approach in the longer term is to reduce our overall dependence on animal products, but this will require major changes to lifestyle and social structure. A more immediate option is to increase production efficiency, a critical component of which is the efficiency with which nutrients are utilized during animal growth and production.

The importance of fully understanding the role of nutrient utilization in animal production enterprises has been recognized for a long time, but the controlling factors are numerous and only partially elucidated. As a further complication, there is a strong link between nutrient supply and intermediary metabolism. It is therefore of no surprise that the relationship between nutrients and production efficiency is complex and can sometimes lead to unexpected responses. Since the overall efficiency of any particular production-related animal characteristic is under polygenic control, incremental gains are readily achievable by selective breeding from elite animals. The rate of gain that can be achieved by this approach is of the order of $2-$ $4 \%$ per generation (Lindsay, 1998) and since this can be sustained for many generations, the practical outcome for the farmer is a substantial cumulative gain. To give two simple examples, over the past 50 years milk yields from dairy cows have risen from $2000 \mathrm{~kg}$ to more than $5000 \mathrm{~kg}$ per lactation and the daily liveweight gain of swine has increased from $450 \mathrm{~g}$ to more than $800 \mathrm{~g}$ (Tribe, 1998), both largely due to improvements in nutrition and the base genetic stock.

The efficiency of nutrient utilization is an important physiological component of the productivity improvement that is possible by conventional genetic selection. However, selective breeding programs do not require an understanding of the genes involved in the targeted production characters. Improvements arise from the selection of more optimal gene combinations identified on the basis of improved phenotypes. The genetic variation that forms the basis of this selection process is derived from random mutation of the parent genomes. The individual mutations generally involve only minor variations in activity between various alleles, and measurable effects on specific phenotypes are obtained by producing large numbers of progeny and thus examining many of the possible gene combinations. The approach is inevitably quite slow because each increment of improvement requires a full generation interval. Furthermore, in those instances where a single gene of large effect is identified, it is not possible to transfer such an allele without simultaneously transferring an entire haploid genome from the donor animal because of the limitations imposed by natural mating.

\section{Transgenic technology}

With the advent of recombinant DNA techniques, it has become possible to transfer single genes as recombinant DNA between animals and this provides a new dimension to genetic selection techniques, because it then becomes possible to target specific genetic properties at the level of the DNA code, instead of utilizing the correlations used in objective selection techniques. However, the fledgling technology introduces a number of new problems which are summarized below.

Animals that successfully incorporate recombinant DNA into their genomes are defined as transgenic and the recombinant DNA itself is known as a transgene. The origins of this extraordinary technology in eukaryotes can be traced back to the experiments of Wigler et al. 
(1979) who demonstrated that 'naked' DNA could be taken up by eukaryotic cells and become part of the functional genome of the 'transfected' cells. The efficiency of incorporation was low, of the order of $10^{-3}$ to $10^{-4}$, but since cell culture methods can provide large numbers of cells, this was not a major technical problem. As the ability to isolate and manipulate genetic information by recombinant DNA techniques matured during the 1970s, it became apparent to a number of laboratories that it might be possible to extend the transfer of recombinant DNA from cultured cells to living organisms if the DNA could be integrated into embryonic cells at a very early stage of development, ideally at the single cell stage. To achieve this, however, a significant increase in transfer efficiency was required because such cells could only be obtained in small numbers. The various techniques that have been used to transfer DNA to embryos are briefly summarized as follows.

\section{Microinjection}

The most commonly used technique for the introduction of foreign DNA into embryonic cells has been that of pronuclei microinjection, although it appears likely that the rapidly emerging technique of nuclear transfer, discussed shortly, may soon replace it. An excellent review of microinjection technology and its history of development is provided by Palmiter \& Brinster (1986) and hence its details will only be briefly summarized here. The technique was pioneered in laboratory mice and as originally described involved the collection of several hundred single cell embryos obtained from donor animals by conventional reproductive techniques. A small quantity of recombinant DNA was introduced into one of the pronuclei of each embryo by microinjection, involving the insertion of a fine needle into the embryo pronucleus and the injection into this organelle of about $2 \mathrm{pl}$ solution. The embryos were then briefly cultured and survivors transferred to recipient mothers with reproductive cycles suitably synchronized to accept the embryos. The efficiency of the technique increased by several orders of magnitude the integration of foreign DNA into target nuclei compared with that achievable using standard cell culture transfection procedures, although it was nevertheless still an inefficient process. A summary of eighteen studies involving 12314 injected mouse embryos gives a figure of 2.6 transgenic animals produced per 100 embryos injected and transferred (Wall, 1996).

Although minor variations in the procedures are required, the general principles of microinjection developed for mouse embryos are applicable across a wide range of species, including domestic animals. Most of the early work pioneering the application of the technique to domestic animals was carried out by Hammer and colleagues (Hammer et al. 1985) with an emphasis on swine. As more laboratories became involved it became apparent that the efficiency of integration of transgenes into most domestic species was substantially lower than that achievable in mice. The transgene integration efficiencies per embryo injected are 0.7 per 100 for cattle, 0.9 per 100 for swine and sheep (Wall, 1996). While a detailed study of the factors involved in the optimal incorporation of transgenes into mice has been made (Brinster et al. 1985), no similar study has been carried out for domestic animals. A major problem in domestic animal embryos is the presence of dense cytoplasmic granules which tend to obscure the pronuclei during the microinjection procedure. While the problem is less apparent in sheep and goats than in pigs and cattle, and can be partially overcome by centrifugation of the embryos before microinjection, it presents difficulties in all species of larger animals. Whether it is the only factor involved in the lower integration efficiencies found in domestic animals is not known.

Mention should also be made of the use of a variant of microinjection in the production of transgenic chickens. This approach has been reviewed in detail elsewhere (Perry \& Sang, 1993; 
Sang, 1994) and consists of microinjecting large quantities of DNA into the cytoplasm of fertilized eggs in the vicinity of the male and female pronuclei and then allowing the eggs to develop using a specialized culture technique. The first generation of chickens produced by this technique are highly mosaic for the integrated DNA but lines of chickens with stable germ-line integrations can be established by normal breeding techniques (Mather et al. 1994; Karapetiyan, 1997). While this approach has little applicability to large domestic animals, it is an important route at present for the production of transgenic birds. However, recent advances in the use of retrovirus vectors and liposome-mediated transfection are also of value in avian applications, as indicated in the following sections.

\section{Retroviruses}

The use of retroviruses to transfer DNA to embryos has been investigated by several groups as a potential route for gene transfer (for review, see Valerio, 1992). While this route has some attractive features, until recently it has appeared to be of limited application to the production of domestic transgenic animals. However, two novel modifications of the technology have recently been reported that may widen its applicability and safety in domestic animals. The general approach involves several discrete steps. Initially, a disabled retrovirus must be constructed that contains a partially functional genome that is missing one or more of the genes required for viral packaging and/or infection. These missing viral components are supplied on a one-off basis by the use of a helper virus. The disabled viral genome must then be modified by integration of the transgene into its sequence. There are some limitations to the size of insert that can be accommodated by retroviruses, with an upper limit of about $10 \mathrm{~kb}$ frequently accepted (Gelinas \& Temin, 1986). Once the retroviral nucleotide sequence is constructed, infectious viral particles are produced by incubation of the disabled virus with a helper virus that provides the missing components needed for construction of a fully infectious particle. The infectious virus can then be used to infect cells of the target animal, in principle incorporating itself and the associated transgene into the target genome.

Several problems have been identified with this approach. It is mandatory that the viral sequence carrying the transgene is totally disabled and incapable of producing infectious viral particles on its own, since this would enable uncontrolled spread of the transgene through the target species. There is some debate about how effective the disablement of retroviruses is (Bosselman et al. 1989). It has also been found that a high level of mosaicism occurs for the integration of the retrovirus, with many transgenic animals not containing the transgene in the germ-line (Stewart et al. 1987). Expression of the transgene is also unpredictable for reasons as yet undiscovered (Jaenisch, 1988).

Recently, two novel modifications of the retroviral approach have been reported. In the first case, a self-inactivating vector has been designed with the properties of self-excision of the long terminal repeat sequences needed for infection (Hofman et al. 1996). This should provide significantly greater levels of safety in the use of this process. The second recent modification offers substantially increased efficiencies of integration. In this work, a disabled retroviral vector containing a DNA insert was injected directly into cattle oocytes, which are arrested in metaphase II before fertilization (Chan et al. 1998). The hypothesis put forward by these authors was that the nuclear material was likely to be considerably more accessible to retroviral integration at this time because the nuclear envelope would have broken down as part of the oocyte maturation process. The results appear to support their concepts, since four calves (three female, one male) were born from embryos developed from treated oocytes and all four animals 
were transgenic. Furthermore, the male animal was shown to contain the transgene in its semen and when oocytes were fertilized with this semen, five of the nine embryos examined were transgenic, indicating proper Mendelian segregation.

It will be of interest to see how effective this can be in ensuring that no infectious viral particles are produced from infected cells, but it would seem likely that a combination of a multiply disabled vector incorporating self-inactivation after integration might prove of adequate safety.

A refinement of the use of retroviruses is the developing field of transposable elements. These sequences are widely distributed in nature and possess the ability to integrate into target genomes in the same way as for retroviruses. They also have the ability to move between DNA sites within a genome but do not have the infective ability associated with retroviruses. They have been investigated in detail in plants (Federoff et al. 1992) and Drosophila (Sherratt, 1995) but have had little application in animals. Recently, however, the potential for their use in animals has been demonstrated by several studies. The Drosophila element 'mariner' has been shown to transpose into fowls at high frequency and provide germ-line transmission in one of three birds that were produced (Sherman et al. 1998). In another study, a transposable element was 'rescued' from the salmonid genome and shown to be capable of integrating into a range of species including mammals (Hackett et al. 1998). These sequences can be modified to accept a piece of foreign DNA in similar fashion to retroviruses and to integrate this DNA into the target genome together with the essential transposase sequences. Research is still required to demonstrate how effectively such sequences are expressed in their new environment and how stable they are once integrated. However, preliminary reports suggest a high efficiency of integration, thus making it an attractive approach for the production of transgenic animals.

\section{Cell culture-based transfection methods}

A variety of standard techniques that are commonly used for the transfection of cells in culture have been tested as possible methods for the introduction of genes into embryos, but all have proven to be of too low an efficiency to be useful. The methods tested include $\mathrm{CaPO}_{4}$-precipitates, cytoplasmic injection, electroporation and liposomes. However, the use of cell transfection has recently assumed greater importance in the production of transgenic animals because of the advent of nuclear transfer (see later). Also, a recent encouraging report has appeared in the production of transgenic chickens. In this work, fowl blastodermal cells were transfected in culture, enriched by FACS-sorting and used to produce chimaeric embryos of which $35 \%$ were germ-line transgenic (Specksnijder et al. 1999). It is probable that in the near future, most transgenes will be inserted into cells in culture by conventional transfection techniques and the resulting stable lines used to produce transgenic animals.

\section{Sperm-mediated gene transfer}

It has been reported that DNA can be carried into oocytes by adsorbing it to spermatozoa and that this DNA is subsequently integrated into the embryo genomes to produce transgenic animals (Brackett et al. 1971; Lavitrano et al. 1989). The initial excitement produced by these results has subsequently been tempered by the lack of success achieved by many laboratories' attempts to repeat the work (Brinster et al. 1989). However, reports continue to appear at irregular intervals (Sperandio et al. 1996) indicating that there may yet be some merit in the approach, although it must at this stage be considered an unproven technology. 
DNA can be introduced into cells by coating small particles with the transgene of interest and 'firing' the particles into appropriate tissues (Williams et al. 1991). When this is carried out into somatic tissues, expression of the genes is transient and the transgenes do not integrate into the nuclei of the somatic cells or at least integrate with such low efficiency that integration is undetectable (Kerr et al. 1996). It is theoretically possible that if the procedure was carried out with the reproductive tissues as target, some integration of the transgene might be obtained which could give rise to a transgenic animal. There are no reports that this has been tested experimentally and to date the technique remains of value for measuring transient expression of transgenes in specific tissues but is of little value in the production of stable transgenic lines of animals.

\section{Nuclear transfer}

The technique that appears poised to supplant microinjection as the preferred method for the introduction of transgenes to domestic animals is the recently developed procedure of nuclear transfer. This offers a significant improvement in the efficiency with which transgenic livestock might be produced and in addition has the potential to provide some very useful additional capabilities for the modification of the target genome. In contrast to the microinjection technique, whereby a transgene is added directly to the genome of an embryo, the new technique of nuclear transfer involves the introduction of a transgene to cells maintained in cell culture and the use of one of these cells as a source of genetic information to program the development of an enucleated oocyte (Campbell et al. 1996; Wilmut et al. 1997). While the mechanism remains poorly understood, it appears that the cytoplasm of the recipient oocyte possesses the ability to 're-program' the DNA of the transformed, cultured cell in such a way that the embryonic developmental program can be commenced from time zero. Based on the pioneering work of Willadsen (1986), the recent technology has been developed by Campbell et al. (1996) and Wilmut et al. (1997) who have discovered the important role of the cell cycle in the process. In essence, it appears that the efficiency of the process is enhanced if the donor cells are placed in the quiescent $G_{0}$ stage of the cell cycle by depriving them of serum in their growth medium. Upon transfer to metaphase II enucleated oocytes, the nuclei of these cells are apparently reprogrammed to undergo the full developmental program normally reserved for zygotes derived by sperm-mediated fertilization. A crucial aspect of the recent discoveries is the finding that somatic cell lines derived from adult tissue can serve as nuclear donors in this process (Wilmut et al. 1997), a remarkable finding recently confirmed in laboratory mice (Wakayama et al. 1998). The technique has also now been extended to the production of transgenic cattle (Cibelli et al. 1998), indicating its probable wide applicability to many domestic animal species. This latter paper also questions the need for donor cells to be in the $G_{0}$ phase of the cell cycle, a crucial finding, if confirmed, since it has significant implications for the intellectual property rights associated with the widespread commercial use of the technology.

There are many clear advantages to the use of nuclear transfer compared with microinjection as a method of introducing transgenes to domestic animals. Since the transgene is first introduced to cells in culture, this overcomes the highly inefficient and time-consuming step of using fertilized embryos as the target for gene integration. Cultured cells can be obtained in large numbers and recombinant DNA is readily introduced to these cells by a variety of wellproven techniques. Selected cells can be made into clonal lines and evaluated for site and stability of integration and in some cases can even be tested for expression, all under conditions 
of cell culture, before using them for the production of transgenic animals. In addition, for cells in culture, techniques are available to carry out homologous recombination between the recombinant DNA and the equivalent homologous gene in the target cell, thus allowing specific genes to be inactivated or replaced by variant alleles. This adds a powerful new capability to gene manipulation of domestic animals, since the potential is for genes to be added, inactivated or replaced in specific animal lines. At its current stage of development, nuclear transfer is still in an experimental phase but it appears well-placed eventually to replace microinjection as the method of choice in introducing transgenes to domestic animals.

\section{Transgenic approaches to the alteration of nutrient utilization}

The demonstration by Palmiter et al. $(1982,1983)$ that the phenotype of an animal could be altered by recombinant DNA initiated a range of research programmes directed towards the improvement in production efficiency. It is an indication of the difficulty of the technology and our incomplete understanding of the physiological processes of animals that none of these projects has yet achieved an outcome that enables it to be used at a production level on the farm. Improvements in the gene transfer technology, as described above, may improve the chances of success, but a better understanding of the underlying physiological processes is also crucial. With this in mind, the areas that have been subjected to investigation are reviewed below, together with some comment on the progress that might be expected over the next few years.

\section{Manipulating the endocrine system}

The large physiological effects that can be produced by small changes in the levels of circulating hormones make the endocrine system an attractive target for genetic manipulation. To alter body growth, carcass composition and feed utilization efficiency, an obvious endocrine target is the suite of peptide hormones comprising growth hormone (GH), growth hormonereleasing factor (GRF), insulin-like growth factor-1 (IGF-1), insulin, and thyrotrophic hormone, because these hormones are widely believed to control body growth and tissue development. The hormone chosen for initial experimentation was GH itself, for two reasons. First, the administration of exogenous GH to animals has been shown to increase feed utilization efficiency, increase growth, and produce a leaner carcass composition (for reviews, see Spencer, 1985; Sejrsen, 1986; Florini, 1998). Second, the pioneering research of Palmiter et al. (1982, 1983) in transgenic mice demonstrated the feasibility of influencing the phenotype of transgenic animals by inserting novel genes into their genomes that altered the circulating levels of GH. In domestic animals the bulk of the early data have been generated in swine and sheep, although there is some recent information pertaining to fish. It is now clear from these results that when the level of circulating GH is elevated there are a number of physiological changes that occur in all the animals studied, but that in addition there are changes to phenotype that appear to be species-specific. The results also demonstrate that it is important to avoid consistently high levels of the hormone, identifying the need for precise regulation of the expression of the transgene. The major observations from these studies are summarized below.

The range of GH-related transgenes that have been used in domestic animals is shown in Table 1, together with the number of transgenic animals produced and expressing these genes. Five of these genes have been designed directly on the basis of the work of Palmiter et al. $(1982,1983)$ and consist of a GH-coding sequence joined to a regulatory sequence derived 
from a metallothionein (MT) gene. However, in later experiments, modification to this basic design was carried out in an attempt to provide more precise control of the expression of the gene. In total, ninety-six founder transgenic pigs and thirty-five founder transgenic sheep have been produced, with fifty-three of these animals expressing the inserted gene (forty-one pigs and twelve sheep).

Common to transgenic swine and transgenic sheep was a large depletion in body fat, an increase in muscle mass and an increase in the size of the visceral organs (Hammer et al. 1985; Pursel et al. 1989; Rexroad et al. 1990; Nancarrow et al. 1991; Pursel \& Solomon, 1993). The most detailed analysis of the results obtained in transgenic swine is by Pursel \& Solomon (1993). These data show an enhanced growth rate $(11.1-13.7 \%)$ as long as the diet was modified to contain increased levels of protein and lysine, which is consistent with results obtained in animals injected with exogenous GH (Goodband et al. 1988; Newcomb et al. 1988). These animals also had feed intake reduced by $17-20 \%$, resulting in an increase of $16-18 \%$ in the efficiency of converting feed into body-weight gain, again consistent with the results obtained by injecting exogenous GH into swine (Campbell et al. 1988; Evock et al. 1988). Detailed examination of the carcass properties of these animals showed that, when separated into the four primal (pork) cuts, the hams of the transgenic animals were significantly larger and the loins significantly smaller than the controls, and the intramuscular fat content was greatly depleted. This reduction in fat content did not, however, appear to affect the overall tenderness of the meat. The actual lipid composition in these animals was also altered. Thus, the fatty acid profile consistently showed a reduction in saturated fatty acids, together with a smaller reduction in mono- and polyunsaturated fatty acids. The overall result of these changes in lipid composition was to move the fatty acid profile closer to a $1: 1: 1$ relationship for saturated to monounsaturated to polyunsaturated fatty acids, a profile which is recommended as optimal for human health.

In contrast to the results obtained with transgenic swine, the growth rates for all the transgenic sheep except those containing the gene oMT-GH10 (see later) were either not increased or in some cases even decreased (Rexroad et al. 1990; Nancarrow et al. 1991). This is consistent with two studies of exogenous GH administered to lambs, both of which reported no significant increase in average daily gain (Muir et al. 1983; Wagner \& Veenhuizen, 1988). Interestingly, a third study found a significant weight gain over controls but this did not result in an increased carcass weight (Johnson et al. 1985).

In addition to the research conducted on domestic swine and sheep, there has been a substantial amount of research obtained with transgenic fish containing GH-encoding transgenes. In stable fish lines, these animals also exhibit increased growth rates, some of which are higher than those seen in transgenic mice. Thus, Maclean et al. (1987) showed that transgenic trout containing a MT-regulated GH-encoding gene grew 3-4.6 times larger than controls and did not have any detectable physical abnormalities, while Du et al. (1992) showed a 2-6-fold increase in the growth of Atlantic salmon containing a gene encoding a unique fusion between a chinook salmon GH-coding sequence and an antifreeze protein gene promoter from ocean pout. Subsequent studies on these latter fish have shown that the transgene is transmitted by Mendelian inheritance to progeny which in turn retain the increased growth-rate characteristics, with an average increase in growth of 11-fold above controls (Devlin et al. 1995, 1998). Studies on the physiology of these fish indicate that they have a 15-20\% increased feed conversion efficiency (Entis, 1997). It is also of interest to note that the transgenic fish are more readily reared in conditions of temperature and photoperiod that optimize growth but which would inhibit normal smolt development and postsmolt performance of non-transgenic salmon (Saunders et al. 1998). Several other species of transgenic fish have also been produced that 
contain modified GH transgenes. The introduction of a gene-encoding salmonid GH increased the growth rate of channel catfish by 30-40\% (Dunham \& Devlin, 1998), a gene-encoding tilapia GH increased the size of F1 progeny at 9 months of age by $82 \%$ (Martinez et al. 1996) and a human GH-encoding gene increased feed conversion efficiency in carp by $30-40 \%$ (Fu et al. 1998).

All the larger domestic transgenic animals produced with MT-regulated GH-encoding transgenes, with the exception of oMT-GH10, showed significant health problems. In swine these included lameness, susceptibility to stress, gastric ulcers, parakeratosis, lethargy, anoestrus in gilts and lack of libido in boars (Pursel et al. 1990). In sheep, similar severe health problems were noted, with the possible exception of gastric ulcers (Ward et al. 1989; Rexroad et al. 1990; Nancarrow et al. 1991). However, the transgenic sheep were prone to diabetes (Ward et al. 1989). In the transgenic coho salmon, the phenotype of the small and mediumsized transgenics was normal, whereas excess cranial and opercular cartilage, together with impaired swimming ability, was apparent in the animals with the high growth rates (RH Devlin, CA Biagi and DE Smailus, unpublished results).

The results obtained with MT-regulated GH-encoding genes suggested that the elevated GH caused a shift in body metabolism towards protein synthesis at the expense of fat and carbohydrates, consistent with the results obtained by exogenous administration of GH. However, sustained elevation of GH concentrations was deleterious to the health of the animals. Accordingly, attempts have been made to regulate the expression of the transgene. Various laboratories have taken different approaches to the solution of this problem. Nottle et al. (1998) introduced a MT-regulated GH-encoding transgene into 296 swine, culled all animals that showed constitutive expression of the transgene and then identified from the remainder those animals that could be induced to express the GH gene by dietary Zn. Twelve animals were identified, four of which did not transmit the gene and seven of which were germline mosaic animals. It thus remains to be seen if any of the germ-line mosaic animals retain the low constitutive but $\mathrm{Zn}$-inducible expression when they are bred to a non-mosaic line in which all cells contain the transgene.

Another solution to improved gene regulation is to change the promoter used to drive expression of the exogenous GH or to change the hormone from $\mathrm{GH}$ to one of the other growthregulating peptides. The range of transgenes that have been constructed and introduced to transgenic animals is shown in Table 1. None of these gene modifications appear to be any more successful than the original MT-regulated GH-encoding genes. However, a novel modification to the ovine MT-GH construction, giving rise to the gene oMTSGH10, appears to be promising. This gene, oMTSGH10, is based on the gene oMTSGH9, which has been described by Shanahan et al. (1989). oMTSGH10 has been constructed in a way that was designed to reduce the level of constitutive and inducible transcription both constitutively and when subjected to $\mathrm{Zn}$ induction (Ward \& Brown, 1998). In contrast to its progenitor, oMTSGH10 has very low expression in transgenic mice and shows no evidence of $\mathrm{Zn}$ inducibility. It has been introduced into one transgenic sheep, from which a line of animals has been made and used to examine the effects of the gene on growth rate and body composition. While some of the data are still being collected, it is already clear that the animals are in good health, grow from the age of about 4 months onwards at a rate between 15-20\% faster than controls, and have a much leaner carcass (Ward \& Brown, 1998). Feed utilization efficiency has been measured from 3.5 months to 7 months of age and was the same as that of controls during this period. This will need to be repeated at later stages of growth. To date, the gene has only been successfully inserted into a single founder animal, from which a line of sheep has been bred through three generations. More founder animals will clearly need to be generated before it can 
Table 1. Details of growth hormone-related transgenes that have been used in domestic animals together with the number of transgenic animals produced and expressing these genes

\begin{tabular}{|c|c|c|c|c|}
\hline Gene & Species & $\begin{array}{l}\text { Transgenics } \\
\text { produced }\end{array}$ & $\begin{array}{l}\text { Transgenics } \\
\text { expressing }\end{array}$ & Reference \\
\hline CMV-pGH & Pig & 15 & 2 & Ebert et al. 1990 \\
\hline \multirow[t]{3}{*}{ mMT-hGH } & Pig & 1 & 0 & Brem et al. 1985 \\
\hline & & 20 & 11 & Hammer et al. 1985 \\
\hline & Sheep & 1 & 0 & Rexroad et al. 1990 \\
\hline \multirow[t]{2}{*}{ mMT-bGH } & Pig & 9 & 8 & Pursel et al. 1987 \\
\hline & Sheep & 2 & 2 & Rexroad et al. 1990 \\
\hline hMT-pGH & Pig & 6 & 1 & Vize et al. 1988 \\
\hline$m L V-p G H$ & Pig & 6 & 1 & Ebert et al. 1990 \\
\hline mLV-rGH & Pig & 1 & 1 & Ebert et al. 1988 \\
\hline \multirow[t]{2}{*}{ mMT-hGRF } & Pig & 7 & 2 & Pursel et al. 1989 \\
\hline & Sheep & 9 & 1 & Rexroad et al. 1990 \\
\hline mTF-bGH & Sheep & 11 & 3 & Rexroad et al. 1988 \\
\hline \multirow{2}{*}{ mAL-hGRF } & Pig & 5 & 3 & Pursel et al. 1989 \\
\hline & Sheep & 4 & 2 & Rexroad et al. 1990 \\
\hline mMT-hIGF- 1 & Pig & 4 & 1 & Pursel et al. 1989 \\
\hline \multirow[t]{2}{*}{ oMT-oGH9 } & Sheep & 7 & 3 & Murray et al. 1989 \\
\hline & Pig & 15 & 6 & Pursel et al. 1997 \\
\hline oMT-oGH10 & Sheep & 1 & 1 & Ward \& Brown, 1998 \\
\hline PEPCK-bGH & Pig & 7 & 5 & Wieghart et al. 1990 \\
\hline Total & & 131 & 53 & \\
\hline
\end{tabular}

Promoter sequences: MT, metallothionein; PEPCK, phosphoenolpyruvate carboxykinase (EC 4.1.1.49); LV, Moloney leukaemia virus LTR; CMV, cytomegalovirus LTR; TF, transferrin; AL, albumin. Gene sequences: GH, growth hormone; GRF, growth hormone releasing factor; IGF-1, insulin-like growth factor-1.

be unequivocally concluded that the advantageous growth characteristics shown by the current line of animals are likely to be found in all animals containing the oMTSGH10 gene, but when considered together with the results obtained in transgenic mice, these results looks very encouraging.

A third approach to obtaining animals with promising growth performance is that described for pigs by Pursel et al. $(1996,1998)$, in which the IGF-1 gene is controlled by the avian skeletal $\alpha$-actin promoter. Using this transgene, expression of IGF- 1 is primarily confined to the muscle cells and has its effect directly on this tissue. In consequence, average daily weight gain and feed efficiency do not differ from control animals, but the transgenic animals had $11.4 \%$ and $3.3 \%$ less fat and $5.1 \%$ and $2.2 \%$ more protein in the eviscerated carcasses of males and females respectively (Pursel et al. 1998). The IGF-1 concentrations of plasma were between $9 \%$ and $10 \%$ higher than in control pigs and the general health of the animals was good. The avian skeletal $\alpha$-actin promoter has also been used in another approach recently described in mice. In this case the promoter is joined to the gene sequence encoding $\mathrm{GH}$ and the fusion gene inserted into mice by injecting the DNA directly into regenerating quadriceps muscle tissue. This results in the uptake of some of the DNA into the muscle cells, which then produce and secrete GRF in levels sufficient to elevate GH and produce increased body growth (Draghia-Akli et al. 1997).

These results together indicate that the concept of increasing body growth and feed utilization efficiency, whilst simultaneously improving the carcass composition of domestic animals to make it more suitable for human consumption, remains a worthwhile and achievable goal. The difficulty that must still be overcome is the adverse effect on health that results in animals that produce $\mathrm{GH}$ at high levels. However, optimization of GH-encoding genes is progressing to the stage where transgenic animals with genuine commercial application are 
close to reality and might be expected to be in field trials within the next few years. Whether the time taken by this series of projects can be used as a guide to the length of time that any transgenic project might require to progress from initial concept to commercial reality is uncertain, because the technology is maturing at a fast rate and should be enhanced substantially by nuclear transfer as an improved method for the production of transgenic animals. Nevertheless it is clear from the GH research which commenced in domestic animals in about 1984 that transgenic animal research projects are long-term and high-risk and are likely to remain so for some time yet.

\section{The modification of intermediary metabolism}

The evolution of domestic animals has been a complex procedure involving both natural selection and the selection of specific traits aimed at increasing the production of various animal products. However, these two different selection processes do not necessarily work harmoniously together. Natural selection produces animals that are generally well adapted for survival in their natural environment, while selection for specific productivity traits is less concerned with this outcome provided that the animals are compatible with the more controlled production environment in which they are placed. Since the biosynthesis of nutrients requires an input of energy, it is not surprising that metabolic pathways for the synthesis of many of the compounds that are readily available from feed supplies are frequently lost during an evolutionary process driven by natural selection. However, when such animals become the genetic base for the selection for specific production traits, their restricted biosynthetic capability can result in a specific nutrient becoming a limiting factor for production.

One of the more useful features of transgenic technology is its ability to replace missing biosynthetic pathways in animals by transferring to them the relevant functional genes isolated from some other organism. Since much of intermediary metabolism is common across all organisms, prototrophic bacteria are an excellent source for these functional genes because they retain the ability to synthesize most of the compounds of intermediary metabolism. Furthermore, there is now a significant body of evidence accumulating to show that the bacterial enzymes encoded by these genes can have acceptable levels of activity in mammals. Most research in this area so far has been directed towards the goal of increasing the supply of essential amino acids, particularly cysteine, threonine and lysine. However, some progress has also been made towards the introduction of a functional glyoxylate cycle in animals. Of these projects, only the work directed towards the introduction of a functional cysteine biosynthetic pathway has yet reached the stage of being tested in domestic animals. Because it is the most advanced of the current projects, it will be discussed in some detail. However, the general principles inherent in this project apply in general to most projects aimed at introducing new biosynthetic pathways to animals.

Amino acid biosynthetic pathways. The replacement of the biosynthetic pathways for some of the essential amino acids has received considerable attention because these are frequently rate-limiting nutrients for specific production traits. For example, in sheep under some pasture conditions the amino acid cysteine is rate-limiting for wool growth and it has been predicted that wool growth could be increased substantially if this amino acid were freely available (Reis, 1979). Because most ingested nutrients are rapidly metabolized by the rumen microflora in sheep, the simple procedure of feeding additional cysteine to deficient animals is not effective (Reis, 1979) and the sheep is lacking the genes necessary for the enzymes of 


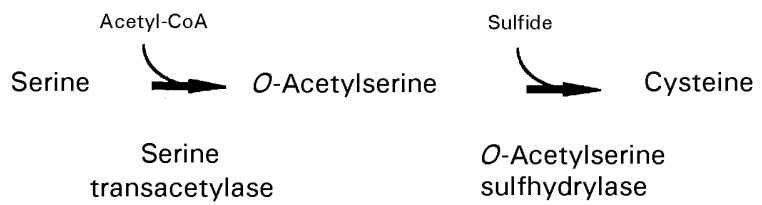

Fig. 1. The carbon pathway portion of the cysteine biosynthetic pathway in E. coli.

cysteine biosynthesis. The relevant biosynthetic pathway in Escherichia coli is shown in Fig. 1. It can be broadly divided into a pathway for the reduction of $S$ to an active form of reduced sulfide and a $\mathrm{C}$ pathway in which, firstly, the amino acid serine is converted to $O$-acetylserine in the presence of acetyl-CoA and the enzyme serine transacetylase (EC 2.3.1.30; SAT), and then the $O$-acetylserine is converted to cysteine in the presence of sulfide and the enzyme $O$-acetylserine sulfhydrylase (EC 4.2.99.8; OAS). The sulfide concentration in the sheep rumen has been reported to be in the range of 0.6 to $288 \mu \mathrm{g} / \mathrm{ml}$ (Bray \& Till, 1975), suggesting that a functional biosynthetic pathway might be possible in sheep if the enzymes SAT and OAS could be provided in the ruminal epithelial cells.

In $E$. coli the cysE gene encodes the enzyme SAT and the cysK or cysM genes encode variants of the enzyme OAS. Accordingly, the cysE (Denk \& Bock, 1987) and cysK (Byrne et al. 1988) genes were isolated and modified for expression in eukaryotic organisms (Leish $e t$ al. 1993). This is a crucial step in any project involving the transfer of genes from bacteria to mammals and the requirements for strong expression of the transgenes in animals is still only partially understood. Briefly, a promoter must be linked $5^{\prime}$ to the bacterial coding sequence such that it will direct expression of the gene in appropriate tissues and a DNA sequence encoding a suitable polyadenylation signal must be linked $3^{\prime}$ to the coding sequence. For the formation of a functional cysteine biosynthetic pathway, the structure of the gene MTCEK1 is shown in Fig. 2. This gene embodies the general principles involved in altering a bacterial gene sequence to a functional eukaryotic gene. Various other constructions have also been made and tested and these are summarized in Leish et al. (1993).

The ability of the gene MTCEK1 to provide a functional cysteine biosynthetic pathway in mammals has been demonstrated in several different ways. Initial testing of the gene was carried out in eukaryotic cells, demonstrating that the bacterial enzymes could be synthesized at

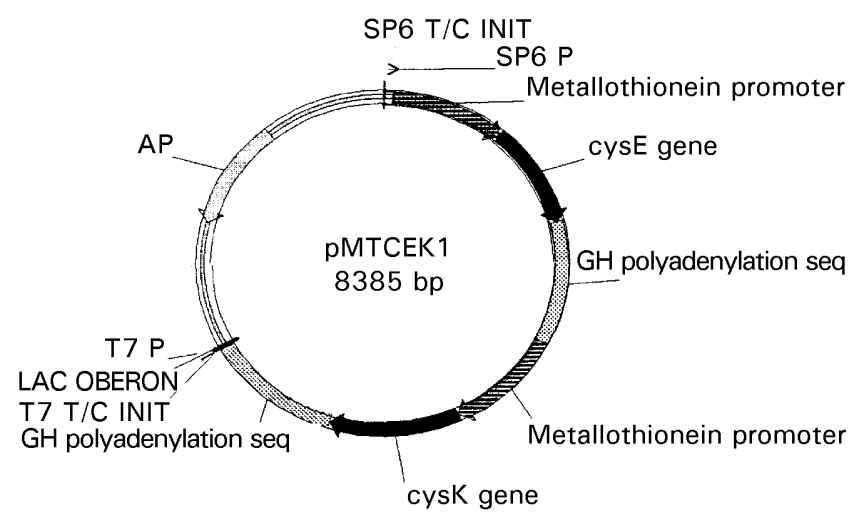

Fig. 2. The gene MTCEK1 which encodes the cysteine biosynthetic pathway shown in Fig. 1. 
high levels in that they were very active and stable in such cells (Ward \& Nancarrow, 1991; Leish et al. 1993). The gene was then introduced into transgenic mice where it was shown to be expressed at high levels in several tissues including the small intestine (Ward et al. 1994). When this intestinal tissue was incubated with sulfide, the synthesis of cysteine was clearly demonstrated. The most convincing demonstration of the functionality of the cysteine pathway in transgenic mice, however, was obtained by a dietary study in which transgenic mice and appropriate control mice were placed on a synthetic diet which was supplemented with $\mathrm{Na}_{2} \mathrm{~S}$ but in which the sulfur amino acids cysteine and methionine were reduced in concentration to low levels. After $7 \mathrm{~d}$ on this diet, substantial hair loss and weight loss were experienced by the control animals but the transgenic animals continued to grow normally and did not lose any hair (Ward et al. 1994).

One of the crucial requirements for the modification of animal biochemistry is that the new pathway be compatible with the existing intermediary metabolism of the animal. In the case of the transgenic mice containing the gene MTCEK1, the new cysteine biosynthetic pathway apparently integrates with the animal's existing biochemistry without any difficulty. On the other hand, the pathway appears to be less compatible with the existing intermediary metabolism of sheep. A summary of the results obtained in our own laboratory and that of Rogers and colleagues (Sivaprasad et al. 1992; Bawden et al. 1995) is provided by Ward et al. (1998). Briefly, these show that twenty-eight transgenic sheep with the genes encoding cysteine biosynthesis have been produced. These animals contain the bacterial coding sequences for the enzymes SAT and OAS, isolated either from E. coli or from Salmonella typhimurium (Sivaprasad et al. 1992) and regulated by three different eukaryotic promoters. However, no useful expression of the genes has been obtained in any of these animals, although some low-level expression has been detected (Bawden et al. 1995; Ward et al. 1998). In addition, the number of transgenic animals produced as a percentage of embryos microinjected is low compared with the efficiency obtained for other genes (Ward et al. 1998). An obvious explanation for these results is that high levels of expression of a cysteine biosynthesis pathway in sheep embryos is lethal, so that the only transgenic animals obtained are those in which the genes have been inserted in a region of the genome that prevents their expression or at best allows only low levels of expression. Two possible explanations have been put forward to explain these results. The first is that during embryogenesis an unacceptable depletion of the co-factor acetyl-CoA occurs as a result of the unregulated operation of the first step of the pathway involving serine and acetyl-CoA (Ward et al. 1998). This step is catalysed by the enzyme SAT, which is inhibited by high levels of cysteine. However, normal intracellular levels of cysteine are low and sulfide levels in the embryo would be expected to be insignificant, thus preventing the operation of the full pathway proceeding to cysteine biosynthesis. The SAT would therefore be free to operate in an unregulated manner without any product inhibition. Acetyl-CoA is unlikely to be in short supply in an adult ruminant because the abundant supply of acetate produced by the rumen micro-organisms is readily converted to acetyl-CoA by the enzyme acetylCoA synthase (EC 6.2.1.1) (Van Soest, 1982). However, this is not the case in the embryo during early development because, as found in most mammalian embryos, acetyl-CoA synthase activity is very low (Waugh \& Wales, 1993). This does not cause any difficulties in embryos which can convert glucose to lactate, but this option is blocked in the ruminant blastocyst by a low activity of the enzyme pyruvate kinase (EC 2.7.1.40) (Rieger \& Guay, 1988). The developing ruminant is therefore critically dependent on the introduction of oxidizable substrates to the tricarboxylic-acid cycle and in consequence a fully-functional tricarboxylic-acid cycle to deal with them. The unregulated operation of SAT in the cytoplasm of these embryos would be expected to lower cytoplasmic and hence mitochondrial acetyl-CoA levels and such 
depletion might reasonably be expected to affect adversely the energy supply to the developing embryo.

The other possible explanation is that the pathway is fully operational in the embryo allowing toxic levels of free cysteine to accumulate in the cells (Bawden et al. 1995). While this would appear less likely because of the lack of sulfide in the embryo, it can nevertheless not be excluded at present. Regardless of which explanation is correct for the difficulties experienced in duplicating, in sheep, the functionality of the pathway that was obtained in transgenic mice, it is clear that several possibilities need to be examined. On the assumption that the pathway is not totally incompatible with the intermediary metabolism of adult ruminants, a promoter needs to be found that regulates expression of the genes only to the rumen epithelium and which also prevents such expression until after the birth of the animal.

While the research directed towards the introduction of a cysteine biosynthetic pathway is the most advanced example of the use of genetic engineering to modify the intermediary metabolism of an animal, several other projects are in earlier stages of development. One of these is the proposal to introduce the pathways for the biosynthesis of the amino acids threonine and lysine to non-ruminants (Rees et al. 1990), since these amino acids need to be added to cereal protein for maximal utilization. An interesting and valuable aspect of this paper was the use of computer simulation to predict the flux of biosynthetic products produced by the introduction of a novel pathway to an animal. However, the general concepts of the cysteine biosynthesis project described earlier are equally applicable to threonine and lysine, but the pathways are more complex and this raises some logistical problems. In contrast to the relatively simple two-gene pathway required for cysteine biosynthesis, the biosynthesis of threonine involves four genes and that of lysine a minimum of eight genes. Because the objective becomes more complex as the number of genes increases, the introduction of a threonine pathway by the same strategy as that adopted for the cysteine biosynthesis pathway would be difficult, while the introduction of a lysine biosynthesis pathway would be unlikely to succeed. The main problem encountered in the construction of multi-enzyme pathways is the technical difficulty of modifying each bacterial gene to replace its bacterial promoter sequence with an appropriate eukaryotic promoter and then assembling the genes into a single piece of DNA in preparation for gene transfer. Several novel approaches to overcome some of the difficulties associated with pathways requiring large gene numbers have been proposed. In order to overcome the need for multiple promoters within a multi-gene complex, the coding sequences for each of the required enzymes can be fused to provide a single DNA sequence encoding the required polypeptides under the control of a single eukaryotic promoter. There are two ways in which the desired enzymic activities can be obtained from the mRNA transcript of such multifunctional DNA sequence. The first invokes the use of the encephalomyocarditis virus internal ribosomal entry site DNA sequence which, interspersed between two coding sequences of a single mRNA, allows the initiation of translation to occur both at the start of the mRNA and also internally within the mRNA, resulting in the production of two separate polypeptides. Initially described by Kim et al. (1992), this concept has been subjected to significant commercial development and a number of vectors are now available providing considerable flexibility in the construction of appropriate DNA sequences. The disadvantage of internal ribosomal entry sites is the significant reduction in translation of the downstream polypetide compared with the upstream protein, making the approach inappropriate for those situations where the desired enzymic activities need to be present at similar levels. The alternative approach that is receiving considerable attention is the production of a single polypeptide which folds to a tertiary structure that provides several catalytic sites (for references, see Robinson \& Sauer, 1998). This field is progressing rapidly as structure-function predictions of proteins 
become more sophisticated and promises to be an effective way of reducing the amount of DNA required to encode metabolic pathways. A closely related example in plants consists of a three-enzyme complex designed to catalyse a portion of the mannityl opine biosynthetic pathway complex (von Bawden et al. 1995). The gene was constructed by fusing the relevant coding sequences together and placing a single strong plant promoter at the $5^{\prime}$ end of the complex. Each coding sequence was separated by a short DNA sequence encoding the recognition sequence for a site-specific protease. In addition, the coding sequence for the actual protease required for the recognition of these cleavage sites was also included in the multi-gene tandem array. This elegant construction produces a single polypeptide translation product which is then cleaved in cis by the encoded protease to give rise to the separate enzyme proteins which were able to catalyse the appropriate reactions. A combination of this approach and fusion peptides which are multi-functional, without the need for proteolytic cleavage, would be able to catalyse complex pathways. It will be interesting to follow up this research with studies to determine how many enzymes can be encoded in a single piece of DNA in this way.

The glyoxylate cycle. While the introduction of biochemical pathways for the biosynthesis of essential amino acids is receiving most attention at present, a challenging project is also in progress aimed at introducing a functional glyoxylate cycle to ruminants (Byrne, 1990; Ward \& Nancarrow, 1991) which would allow such animals to synthesize glucose from the abundant supplies of acetate they receive from the rumen. Ruminants are substantially less efficient in their utilization of feedstuff compared with single-stomached animals and one of the major reasons for this is thought to be the lack of glucose available to them for direct absorption from the gut (Bergman, 1975; Van Soest, 1982). There are several tissues in ruminants that could conceivably benefit from the ability to synthesize glucose directly from acetate. These include the mammary epithelium, due to the high carbohydrate content of milk, and the sheep wool follicle, which has an extremely active pentose phosphate pathway thought to be involved in the maintenance of the cellular redox potential during keratin protein biosynthesis (Chapman \& Ward, 1979).

A functional glyoxylate cycle requires the presence of two enzymes, isocitrate lyase ( $E C$ 4.1.3.1) which cleaves isocitrate to succinate and glyoxylate, and malate synthase (EC 4.1.3.2), which catalyses the fusion of glyoxylate and acetyl-CoA to form malate (Ward \& Nancarrow, 1991). The aceA and aceB genes of $E$. coli encode these two enzymes and both genes have been isolated, characterized and assembled into a fusion gene construct MTAceAB1 (Byrne, 1990) which is similar in structure to that of the gene MTCEK1 encoding cysteine biosynthesis (Leish et al. 1993) (Fig. 2), except that the cysE and cysK coding sequences have been replaced by the ace A and aceB coding sequences. This DNA has been introduced into mammalian cells in culture and shown to be actively transcribed and translated into the appropriate enzymes (Byrne, 1990; Ward \& Nancarrow, 1991), a valuable piece of information that demonstrates that the glyoxylate cycle can apparently co-exist with existing biochemistry in a mammalian cell without sequestering the new enzymes in specific organelles. The same gene has also been inserted into transgenic mice and has been shown to be expressed in a variety of tissues including the liver and small intestine (Saini et al. 1996). The level of expression in these animals was not as high as that found for the gene MTCEK1 and the reason for this is not yet known. It may be that more animals have to be produced in order to generate one with a high level of expression. However, it is interesting that attempts in our laboratory to insert the gene into sheep have been unsuccessful so far. It is conceivable that high expression of a glyoxylate cycle in an animal may not be well tolerated, in which case the gene will need to be constructed with promoters that can be regulated and which can direct expression to specific tissues such as the mammary epithelium, the ruminal epithelium and the skin, where the increased production 
of glucose might be advantageous. This research will benefit from the nuclear transfer technology as it matures into a useful method for transgenic animal production, because the pathway can be introduced and examined for functional integration within its new genome before its transfer to animals.

\section{The modification of digestion}

The process of digestion, particularly in non-ruminants, provides another potential target for modification by transgenic techniques. The intestinal tract offers numerous targets, one of the most attractive being the secretion of novel degradative enzymes into the digestive system to provide a mechanism for the utilization of feedstuffs that normally escape digestion and absorption. Obvious substrates are dietary cellulose and xylan, which are inefficiently degraded in non-ruminants by microbial fermentation in the hindgut. It follows that the introduction of cellulase (EC 3.2.1.4) activity into the small intestines of non-ruminants would significantly enhance the nutrient value of plant-based feedstuffs to these animals (Hazlewood et al. 1989; Forsberg et al. 1993).

An innovative research programme has been initiated in this area and has made significant progress towards the eventual modification of domestic animals, summarized as follows. The enzyme chosen for introduction to the digestive tract was the bacterial endoglucanase $\mathrm{E}$ ( $E C$ 3.2.1.6) from Clostridium thermocellum. After isolation and characterization of the appropriate bacterial enzyme, an important step in this work was the demonstration that a truncated form of this enzyme could be secreted by eukaryotic cells in an enzymically active conformation (Hall et al. 1988, 1990; Soole et al. 1993). The DNA encoding this enzyme was then fused to a pancreas-specific enhancer region of the elastase I (EC 3.4.21.36) gene and inserted into the genomes of transgenic mice. These animals produced the truncated cellulase mRNA only in the pancreas and secreted enzymically active cellulase protein into the small intestine (Hall et al. 1993). This is a finding of some significance to the concept of digestion modification, because it demonstrates not only that the bacterial enzyme is stable in the environment of the small intestine but that a mechanism has been discovered for the secretion of heterologous proteins from the exocrine pancreas into the lumen of the small intestine.

The level of expression of the cellulase in the transgenic mice reported by Hall et al. (1993) appears too low to provide significant improvement in the digestion of an animal and the project is currently in the process of increasing the level of expression to that approximating the expression of the normal elastase I gene (Ali et al. 1995). This is reminiscent of the work required for the introduction of the cysteine biosynthetic pathway to animals, which required the construction of a range of gene variants in order to obtain one with sufficient expression in transgenic mice. It is also of interest to note that, just as for the bacterial genes of the cysteine biosynthetic pathway and the glyoxylate cycle, the introduction of intron sequences into the cellulase gene construct did not improve the level of expression in mice. This may thus prove to be a feature of many bacterial genes as they are expressed in mammalian cells.

\section{Conclusions}

Transgenic techniques offer a wide range of possibilities for the improvement of nutrient utilization in domestic animals, but it has yet to be demonstrated that any of these can be brought to fruition. There are, however, several projects that appear to be making progress 
towards this goal. The most advanced are those that involve the modification of growth and carcass composition by the introduction of transgenes that alter the level of circulating hormones involved in the control of body growth. Judged by current rates of progress, it is possible that genetically modified pigs and sheep could be in field trial within the next few years. This will undoubtedly stimulate some debate within the community about the suitability or otherwise of genetically modified meat for human consumption, if the debate currently in progress concerning genetically modified plant foods is any guide. However, the improved carcass composition of such animals is likely to be an appealing feature to the consumer and the improved feed utilization efficiency would be attractive to the producer.

The introduction to the farm environment of animals with modified biochemical properties is still in the research phase and likely to remain at this point for at least the next 5 years. It is apparent that new pathways interacting with existing intermediary metabolism can be introduced to animals, but the results obtained when the cysteine biosynthetic pathway was moved from mice to sheep demonstrates the species-specific difficulties that can ensue. At present, the introduction of the cysteine biosynthetic pathway to sheep appears to be the project closest to application, but there remain several crucial areas of research yet to be completed before this can take place. The introduction of the glyoxylate cycle to ruminants is much further from completion but holds the promise of a greater long-term impact on animal agriculture. As mathematical models become more sophisticated in their ability to predict performance on the basis of feed intake, it will be valuable to attempt to model the expected impact of a glyoxylate cycle on ruminant performance.

A major stimulus to the current application of transgenic techniques to agriculture will come from the recently developed methods of nuclear transfer and animal cloning. These techniques allow the introduction and preliminary testing of DNA constructions in cells in culture and then to use such cells to produce viable animals containing the recombinant DNA. It has been apparent for some years that the ability to produce whole organisms from cultured cells has been one of the major advantages held by those scientists working with plants compared with those working with animals, allowing the genetic modification of plants to proceed very quickly in recent years. As we face the challenges of an expanding food demand in the next several decades, the ability to accelerate the genetic modification of animals will be of vital importance.

It is clear that there are significant areas of nutritional physiology that are still only partially understood. There remains much to be discovered concerning the detailed interaction of nutrients in the intermediary metabolism of ruminants. Transgenic animals may help to shed some light on these problems and, in return, a better understanding might identify additional genetic alterations relevant to the improvement of productivity. It will be interesting to observe progress over the next 5 years as the new techniques in the area of transgenesis are brought to bear on these issues.

\section{Acknowledgements}

I am grateful to my colleagues Drs Jim Murray, Colin Nancarrow, Alan Brownlee, Zdenka Leish and Mr Bruce Brown for their help in the original research described in this paper. I am also indebted to the expert technical assistance of Mrs Nola Rigby, Mrs Cathy Pruss, Miss Tania Radziewic, Mr Alan Fawcett, Mr John O'Grady, Mrs Jenny Gordon, Mr Peter Mitchell and Mr Jim Marshall. Some of the research described in this paper was supported by the International Wool Secretariat. 


\section{References}

Ali S, Hall J, Soole KL, Fontes CMGA, Hazlewood GP, Hirst BH \& Gilbert HJ (1995) Targeted Expression of Microbial Cellulases in Transgenic Animals. Carbohydrate Bioengineering. Proceedings of an International Conference, Elsinore, Denmark, 23-26 April, 1995, pp. 279-293 [SB Petersen, B Svensson and S Pedersen, editors]. Amsterdam, The Netherlands: Elsevier Science Publishers.

Bawden CS, Sivaprasad AV, Verma SK, Walker SK \& Rogers GE (1995) Expression of bacterial cysteine biosynthesis genes in transgenic mice and sheep: toward a new in vivo amino acid biosynthesis pathway and improved wool growth. Transgenic Research 4, 87-104.

Bergman EN (1975) Production and utilization of metabolites by the alimentary tract as measured in portal and hepatic blood. In Digestion and Metabolism in the Ruminant, pp. 292-305 [IW McDonald and ACI Warner, editors]. Armidale, Australia: The University of New England Publishing Unit.

Bosselman RA, Hsu R-Y, Boggs T, Hu S, Bruszewski J, Ou S, Kozar L, Martin F \& Green C (1989) Germline transmission of exogenous genes in the chicken. Science 243, 533-535.

Brackett BG, Boranska W, Sawicki W \& Koprowski H (1971) Uptake of heterologous genome by mammalian spermatozoa and its transfer to ova through fertilization. Proceedings of the National Academy of Sciences, USA 68 , $353-357$.

Bray AC \& Till AR (1975) Metabolism of sulphur in the gastro-intestinal tract. In Digestion and Metabolism in the Ruminant, pp. 243-260 [IW McDonald and ACI Warner, editors]. Armidale, Australia: The University of New England Publishing Unit.

Brem G, Brenig B, Goodman RC, Selden RC, Graf F, Kruff K, Springman J, Hondele J, Meyer E-L, Winnacker EL \& Krausslich H (1985) Production of transgenic mice, rabbits and pigs by microinjection into pronuclei. Zuchthygiene 20, 251-252.

Brinster RL, Chen HY, Trumbauer ME, Yagle MK \& Palmiter RD (1985) Factors affecting the efficiency of introducing foreign DNA into mice by microinjecting eggs. Proceedings of the National Academy of Sciences, USA 82, 4438-4442.

Brinster RL, Sandgren EP, Behringer RR \& Palmiter RD (1989) No simple solution for making transgenic mice. Cell 59, 239-241.

Brown LR (1997) Facing the prospect of food scarcity. In State of the World 1997, pp. 23-41 [LR Brown, JN Abramovitz, C Bright, C Flavin, HF French, G Gardner, AP McGinn, M Renner, DM Roodman and L Starke, editors]. London: Earthscan Publications Ltd.

Byrne CR (1990) The isolation of bacterial acetate metabolism genes and their expression in a eukaryote. PhD Thesis. Macquarie University, Sydney, Australia.

Byrne CR, Monroe RS, Ward KA \& Kredich NM (1988) DNA sequences of the csyK regions of S. typhimurium and E. coli and linkage of the cysK regions to ptsH. Journal of Bacteriology 170, 3150-3157.

Campbell KHS, McWhir J, Ritchie KA \& Wilmut I (1996) Sheep cloned by nuclear transfer from a cultured cell line. Nature 380, 64-66.

Campbell RG, Steele NC, Caperna TJ, McMurtry JP, Solomon MB \& Mitchell AD (1988) Inter-relationships between energy intake and endogenous porcine growth hormone administration on the performance, body composition, and protein and energy metabolism of growing pigs weighing 25 to 55 kilograms live weight. Journal of Animal Science 66, $1643-1655$.

Chan AWS, Homan EJ, Ballou LU, Burns JC \& Bremel RD (1998) Transgenic cattle produced by reverse-transcribed gene transfer in oocytes. Proceedings of the National Academy of Sciences, USA 95, 14028-14033.

Chapman RE \& Ward KA (1979) Histological and biochemical features of the wool fibre and follicle. In Physiological and Environmental Limitations to Wool Growth, pp. 193-208 [JL Black and PJ Reis, editors]. Armidale, Australia: University of New England Publishing Unit.

Cibelli JB, Stice SL, Golueke PJ, Kane JJ, Jerry J, Blackwell C, Ponce de Leon FA \& Robl JM (1998) Cloned transgenic calves produced from nonquiescent fetal fibroblasts. Science 280, 1256-1258.

Denk D \& Bock A (1987) L-cysteine biosynthesis in Escherichia coli: nucleotide sequence and expression of the serine acetyltransferase ( $c y s E)$ gene from the wild-type and a cysteine-excreting mutant. Journal of General Microbiology 133, 515-525.

Devlin RH, Yesaki TY, Donaldson EM, Du ShaoJun, Hew ChoyLeong, Du SJ \& Hew CL (1995) Production of germline transgenic Pacific salmonids with dramatically increased growth performance. Canadian Journal of Fisheries and Aquatic Sciences 52, 1376-1384.

Draghia-Akli R, Li X \& Schwartz RJ (1997) Enhanced growth by ectopic expression of growth hormone releasing hormone using an injectable myogenic vector. Nature Biotechnology 15, 1285-1294.

Du SJ, Gong Z, Fletcher GL, Shears MA, Hooper ML, Melton W, Thomson S \& Smithies O (1992) Growth enhancement in transgenic Atlantic salmon by the use of an all fish chimeric growth hormone gene construct. Biotechnology 10, 176-181.

Dunham RA \& Devlin RH (1998) Comparison of traditional and molecular approaches to genetic improvement in catfish and carp. In Transgenic Animals in Agriculture, pp. 209-229 [JD Murray, GB Anderson, MM McGloughlin and AM Oberbauer, editors]. Wallingford, Oxon.: CAB International. 
Ebert KM, Low MJ, Overstrom EW, Buonoma FC, Roberts TM, Lee E, Mandel G \& Goodman RC (1988) A Moloney MLV-rat somatotropin fusion gene produces biologically active somatotropin in a transgenic pig. Endocrinology 2 , $277-283$.

Ebert KM, Smith TE, Buonoma FC, Overstrom EW \& Low MJ (1990) Porcine growth hormone gene expression from viral promoters in transgenic swine. Animal Biotechnology 1, 145-159.

Entis E (1997) AquaAdvantage salmon: issues in the introduction of transgenic foods. Kungliga Skogs-och Lantbruksakademiens Tidskrift 136, 127-131.

Evock CM, Etherton TD, Chung CS \& Ivy RE (1988) Pituitary porcine growth hormone (pGH) and a recombinant pGH analog stimulate pig growth performance in a similar manner. Journal of Animal Science 66, 1928-1941.

Federoff NE, Botstein DE \& McClintock B (1992) The Dynamic Genome: Barbara McClintock's Ideas in the Century of Genetics. New York: Cold Spring Harbor Laboratory Press.

Florini JR (1998) Hormonal control of muscle cell growth. Journal of Animal Science 61, Suppl. 2, 21-38.

Forsberg CW, Cheng KJ, Krell PJ \& Phillips JP (1993) Establishment of rumen microbial gene pools and their manipulation to benefit fibre digestion by domestic animals. Proceedings 7th World Congress on Animal Production, vol. 1, pp. 281-316. Edmonton, Alberta, Canada: World Congress.

Fu C, Cui Y, Hung SSO \& Zhu Z (1998) Growth and feed utilization by F4 human growth hormone transgenic carp fed diets with different protein levels. Journal of Fish Biology 53, 115-129.

Gelinas C \& Temin HM (1986) Nondefective spleen necrosis virus-derived vectors define the upper size limit for packaging reticuloendotheliosis viruses. Proceedings of the National Academy of Sciences, USA 83, 9211-9215.

Goodband RD, Nelssen JL, Hines RH, Kropf DH, Thaler RC, Schricker BR \& Fitzner GE (1988) The effect of porcine somatotropin (PST) and dietary lysine level on growth performance and carcass characteristics of finishing swine. Journal of Animal Science 66, Suppl. 1, 95.

Hackett PB, Izsvak Z, Ivics Z \& Caldovic L (1998) Development of genetic tools for transgenic fish. In Transgenic Animals in Agriculture, pp. 19-35 [JD Murray, GB Anderson, MM McGloughlin and AM Oberbauer, editors]. Wallingford, Oxon.: CAB International.

Hall J, Ali S, Azim Surani M, Hazlewood GP, Clark AJ, Simons JP, Hirst BH \& Gilbert HJ (1993) Manipulation of the repertoire of digestive enzymes secreted into the gastrointestinal tract of transgenic mice. Biotechnology 11, 376-379.

Hall J, Barker P, Hazlewood GP \& Gilbert HJ (1988) Conserved reiterated domains in Clostridium thermocellum endoglucanases are not essential for catalytic activity. Gene 69, 29-38.

Hall J, Hazlewood GP, Azim Surani M, Hirst BH \& Gilbert HJ (1990) Eukaryotic and prokaryotic signal peptides direct secretion of a bacterial endoglucanase by mammalian cells. Journal of Biological Chemistry 265, 19996-19999.

Hammer RE, Pursel VG, Rexroad CE Jr, Wall RJ, Bolt DJ, Ebert KM, Palmiter RD \& Brinster RL (1985) Production of transgenic rabbits, sheep and pigs by microinjection. Nature 315, 680-683.

Hazlewood G, Mann S \& Gilbert H (1989) Improving forage digestion by genetic engineering. AFRC News July, $12-13$.

Hofman A, Nolan GP \& Blau HM (1996) Rapid retroviral delivery of tetracycline-inducible genes in a single autoregulatory cassette. Proceedings of the National Academy of Sciences, USA 93, 5185-5190.

Jaenisch R (1988) Transgenic animals. Science 240, $1468-1474$.

Johnson ID, Hart IC \& Butler-Hogg BW (1985) The effects of exogenous bovine growth hormone and bromocryptine on growth, body development, fleece weight and plasma concentrations of growth hormone, insulin and prolactin in female lambs. Animal Production 41, 207-217.

Karapetiyan RV (1997) Transgenic chickens produced by microinjecting DNA into the ovum. Russian Agricultural Sciences 3, 34-37.

Kerr DE, Furth PA, Powell AM \& Wall RJ (1996) Expression of the gene-gun injected plasmid DNA in the ovine mammary gland and in lymph nodes draining the injection site. Animal Biotechnology 7, 33-45.

Kim DG, Kang HM, Jang SK \& Shin HS (1992) Construction of a bifunctional mRNA in the mouse by using the internal ribosomal entry site of the encephalomyocarditis virus. Molecular and Cellular Biology 12, 3636-3643.

Lavitrano M, Camaloni A, Fazio VM, Dolci S, Farace MG \& Spadafora C (1989) Sperm cells as vectors for introducing foreign DNA into eggs: genetic transformation of mice. Cell 57, 717-723.

Leish Z, Byrne CR, Hunt CL \& Ward KA (1993) Introduction and expression of the bacterial genes cysE and cysK in eukaryotic cells. Applied Environmental Microbiology 59, 892-898.

Lindsay D (1998) The Australian livestock industries: a case study in non-genetic factors that control genetic improvement. Proceedings of 6th World Congress on Genetics Applied to Livestock Production, vol. 23, pp. 3-9. Armidale, Australia: World Congress.

Maclean N, Penman D, Talwar S \& Tiews K (1987) Introduction of novel genes into the rainbow trout. Heenemann Verlagsgesellschaft $m B H$, vol. 2, pp. 325-333. Berlin: German Federal Republic.

Martinez R, Estrada MP, Berlanga J, Guillen I, Hernandez O, Cabrera E, Pimentel R, Morales R, Herrera F, Morales A, Pina JC, Abad Z, Sanchez V, Melamed P, Lleonart R \& de la Fuente J (1996) Growth enhancement in transgenic Tilapia by ectopic expression of Tilapia growth hormone. Molecular Marine Biology and Biotechnology 5, 62-70.

Mather C, Love J, Gribbina C \& Sang H (1994) The production of transgenic chickens by means of microinjected DNA. Zootecnica International 17, 52. 
Muir LA, Wien S, Duquette PF, Rickes EL \& Cordes EH (1983) Effects of exogenous growth hormone and diethylstilbestrol on growth and carcass composition of growing lambs. Journal of Animal Science 56, 13151323.

Murray JD, Nancarrow CD, Marshall JT, Hazelton IG \& Ward KA (1989) Production of transgenic sheep by microinjection of ovine metallothionein-ovine growth hormone fusion genes. Reproduction, Fertility and Development 1, 147-155.

Nancarrow CD, Marshall JTA, Clarkson JL, Murray JD, Millard RM, Shanahan CM, Wynn PC \& Ward KA (1991) Expression and physiology of performance regulating genes in transgenic sheep. Journal of Reproduction and Fertility 43, Suppl., 277-291.

Newcomb MD, Grebner GL, Bechtel PJ, McKeith FK, Novakofski J, McLaren DG \& Easter RA (1988) Response of 60 to $100 \mathrm{~kg}$ pigs treated with porcine somatotrophin to different levels of dietary crude protein. Journal of Animal Science 66, Suppl. 1, 281.

Nottle MB, Nagashima H, Verma PJ, Du ZT, Grupen CG, MacIlfatrick SM, Ashman RJ, Harding MP, Glannakis C, Wigley PL, Lyons IG, Harrison DT, Luxford BG, Campbell RG, Crawford RJ \& Robins AJ (1998) Production and elevation of growth hormone transgenic pigs. In Transgenic Animals in Agriculture, pp. 145-156 [JD Murray, GB Anderson, MM McGloughlin and AM Oberbauer, editors]. Wallingford, Oxon.: CAB International.

Palmiter RD \& Brinster RL (1986) Germline transformation of mice. Annual Review of Genetics 20, 465-500.

Palmiter RD, Brinster RL, Hammer RE, Trumbauer ME, Rosenfeld MG, Birnberg NC \& Evans RM (1982) Dramatic growth of mice that develop from eggs microinjected with metallothionein-growth hormone GH fusion genes. Nature 300, 611-615.

Palmiter RD, Norstedt RE, Gelinas RE, Hammer RE \& Brinster RL (1983) Metallothionein-human GH fusion genes stimulate growth in mice. Science 222, 809-814.

Perry MM \& Sang H (1993) Transgenesis in chickens. Transgenic Research 2, 125-133.

Pursel VG, Coleman ME, Wall RJ, Elsasser TH \& Haden M (1996) Regulatory avian skeletal alpha-actin directs expression of insulin-like growth factor-1 to skeletal muscle of transgenic pigs. Theriogenology $\mathbf{4 5}, 348$.

Pursel VG, Hammer RE, Bolt DJ, Palmiter RD \& Brinster RL (1990) Genetic engineering of swine: integration, expression and germline transmission of growth-related genes. Journal of Reproduction and Fertility 41, Suppl., $77-87$.

Pursel VG, Miller KF, Bolt DJ, Pinkert CA, Hammer RE, Palmiter RD \& Brinster RL (1989) Insertion of growth hormone genes into pig embryos. In Biotechnology of Growth Regulation, pp. 181-188 [RB Heap, CG Prosser and GE Lamming, editors]. London: Butterworths.

Pursel VG, Pinkert CA, Miller KF, Bolt DJ, Campbell RG, Palmiter RD, Brinster RL \& Hammer RE (1989) Genetic engineering of livestock. Science 244, 1281.

Pursel VG, Rexroad CE Jr, Bolt DJ, Miller KF, Wall RJ, Hammer RE, Pinkert CA, Palmiter RD \& Brinster RL (1987) Progress on gene transfer in farm animals. Veterinary Immunology and Histopathology 17, 303-312.

Pursel VG \& Solomon MB (1993) Alteration of carcass composition in transgenic swine. Food Reviews International 9 , 423-439.

Pursel VG, Wall RJ, Mitchell AD, Elsasser TH, Solomon MB, Coleman ME, DeMayo F \& Schwartz RJ (1998) Expression of insulin-like growth factor-1 in skeletal muscle of transgenic swine. In Transgenic Animals in Agriculture, pp. 131-144 [JD Murray, GB Anderson, MM McGloughlin and AM Oberbauer, editors]. Wallingford, Oxon.: $\mathrm{CAB}$ International.

Pursel VG, Wall RJ, Solomon MB, Bolt DJ, Murray JD \& Ward KA (1997) Transfer of ovine metallothionein-ovine growth hormone fusion gene into swine. Journal of Animal Science 75, 2208-2214.

Rees WD, Flint HJ \& Fuller MF (1990) A molecular biological approach to reducing dietary amino acid needs. Biotechnology 8, 629-633.

Reis PJ (1979) Effect of amino acids on the growth and properties of wool. In Physiological and Environmental Limitations to Wool Growth, pp. 223-242 [JL Black and PJ Reis, editors]. Armidale, Australia: University of New England Publishing Unit.

Rexroad CE Jr, Behringer RR, Bolt DJ, Miller KF, Palmiter RD \& Brinster RL (1988) Insertion and expression of a growth hormone fusion gene in sheep. Journal of Animal Science 6, 267.

Rexroad CE Jr, Hammer RE, Behringer RR, Palmiter RD \& Brinster RL (1990) Insertion, expression and physiology of growth-regulating genes in ruminants. Journal of Reproduction and Fertility Suppl. 41, 119-124.

Rieger D \& Guay P (1988) Measurement of the metabolism of energy substrates in individual bovine blastocysts. Journal of Reproduction and Fertility 83, 585-591.

Robinson CR \& Sauer RT (1998) Optimizing the stability of single-chain proteins by linker length and composition mutagenesis. Proceedings of the National Academy of Sciences, USA 95, 5929-5934.

Saini KS, Byrne CR, Leish Z, Pruss CA, Rigby NW, Brownlee AG, Nancarrow CD \& Ward KA (1996) Introduction and expression of the bacterial glyoxylate cycle genes in transgenic mice. Transgenic Research 5, 467-473.

Sang H (1994) Transgenic chickens - methods and potential applications. Trends in Biotechnology 12, 415-420.

Saunders RL, Fletcher GL, Hew CL, Bromage N, Soivio A, Bjornsson BP \& Eriksson LO (1998) Smolt development in growth hormone transgenic Atlantic salmon. Aquaculture 168, 177-193.

Sejrsen K (1986) Endocrine mechanisms underlying genetic variation in growth in ruminants. In Proceedings of the 3rd World Congress on Animal Genetics Applied to Animal Production, vol. 11, pp. 261-270. Lincoln, NE: University of Nebraska. 
Shanahan CM, Rigby NW, Murray JD, Marshall J, Townrow C, Nancarrow CD \& Ward KA (1989) Regulation of expression of a sheep growth hormone fusion gene in transgenic mice. Molecular and Cellular Biology 9, 5473-5479.

Sherman A, Dawson A, Mather C, Gilhooley H, Li Ying, Mitchell R, Finnegan D \& Sang H (1998) Transposition of the Drosophila element mariner into the chicken germ line. Nature Biotechnology 16, 1050-1053.

Sherratt DJ (1995) Mobile Genetic Elements, Oxford, Oxon.: IRL Press, Ltd.

Sivaprasad AV, Kuczek ES, Bawden CS \& Rogers GE (1992) Coexpression of the cysE and cysM genes of Salmonella typhimurium in mammalian cells: a step towards establishing cysteine biosynthesis in sheep by transgenesis. Transgenic Research 1, 79-92.

Soole KL, Hirst BH, Hazlewood GP, Gilbert HJ, Laurie JL \& Hall J (1993) Secretion of a prokaryotic cellulase in bacterial and mammalian cells. Gene 125, 85-89.

Speksnijder GJ, Etches RJ \& Gibbins AMV (1999) Molecular Reproduction and Development 52, 33-42.

Spencer GSG (1985) Hormonal systems regulating growth: A review. Livestock Production Science 12, 31-46.

Sperandio S, Lulli V, Bacci ML, Forni M, Maione B, Spadafora C \& Lavitrano M (1996) Sperm-mediated DNA transfer in bovine and swine species. Animal Biotechnology 7, 59-77.

Stewart CL, Schuetze S, Vanek M \& Wagner EF (1987) Expression of retroviral vectors in transgenic mice obtained by embryo infection. EMBO Journal 6, 383-388.

Tribe DE (1998) How Sapiens is Homo? Proceedings of 6th World Congress on Genetics Applied to Livestock Production, vol. 23, pp. 10-15. Armidale, Australia: World Congress.

Valerio D (1992) Retrovirus vectors for gene therapy procedures. In Transgenic Animals, pp. 211-246 [F Grosveld and G Kollias, editors]. London: Academic Press.

Van Soest PJ (1982) Nutritional Ecology of the Ruminant. Portland, OR: Durham and Downey.

Vize PD, Mickalska AE, Ashman R, Lloyd B, Stone BA, Quinn P, Wells JRE \& Seamark RF (1988) Introduction of a porcine growth hormone fusion gene into transgenic pigs promotes growth. Journal of Cell Science 90, $295-300$.

von Bodman SB, Domier LL \& Farrand SK (1995) Expression of multiple eukaryotic genes from a single promoter in Nicotiana. Biotechnology 13, 587-591.

Wagner JF \& Veenhuizen EL (1988) Growth performance, carcass deposition and plasma hormone levels in wether lambs when treated with growth hormone and thyroprotein. Journal of Animal Science 47, Suppl. 1, 397.

Wakayama T, Perry ACF, Zuccotti M, Johnson KR \& Yanagimachi R (1998) Full-term development of mice from enucleated oocytes injected with cumulus cell nuclei. Nature 394, 369-374.

Wall RJ (1996) Transgenic livestock: progress and prospects for the future. Theriogenology 45, 57-68.

Ward KA \& Brown BW (1999) The production of transgenic domestic livestock: successes, failures and the need for nuclear transfer. Reproduction, Fertility and Development (In the Press).

Ward KA, Leish Z, Bonsing J, Nishimura N, Cam GR, Brownlee AG \& Nancarrow CD (1994) Preventing hairloss in mice. Nature 371, 563-564.

Ward KA, Leish Z, Brownlee AG, Nancarrow CD \& Brown BW (1998) The utilization of bacterial genes to modify domestic animal biochemistry. In Transgenic Animals in Agriculture, pp. 157-176 [JD Murray, GB Anderson, MM McGloughlin and AM Oberbauer, editors]. Wallingford, Oxon.: CAB International.

Ward KA \& Nancarrow CD (1991) The genetic engineering of production traits in domestic animals. Experientia 47, 913-922.

Ward KA, Nancarrow CD, Murray JD, Wynn PC, Speck P \& Hales JRS (1989) The physiological consequences of growth hormone fusion gene expression in transgenic sheep. Journal of Cellular Biochemistry 13, 164.

Waugh EE \& Wales RG (1993) Oxidative utilization of glucose, acetate and lactate by early implantation sheep, mouse and cattle embryos. Reproduction, Fertility and Development 5, 123-133.

Wieghart M, Hoover JL, McCrane MM, Hanson RW, Rottman FM, Holtzman SH, Wagner TE \& Pinkert CA (1990) Production of transgenic pigs harbouring a rat phosphoenolpyruvate carboxykinase-bovine growth hormone fusion gene. Journal of Reproduction and Fertility Suppl. 41, 89-96.

Wigler M, Pellicer A, Silverstein S, Axel R, Urlaub G \& Chasin L (1979) DNA-mediated transfer of the adenine phosphoribosyltransferase locus into mammalian cells. Proceedings of the National Academy of Sciences, USA 76, 1373-1376.

Willadsen SM (1986) Nuclear transplantation in sheep embryos. Nature 320, 63-65.

Williams RS, Johnston SA, Riedy M, DeVit MJ, McElligott SG \& Sanford JC (1991) Introduction of foreign genes into tissues of living mice by DNA-coated microprojectiles. Proceedings of the National Academy of Sciences, USA 88, $2726-2730$.

Wilmut I, Schnieke AE, McWhir J, Kind AJ \& Campbell KHS (1997) Viable offspring derived from fetal and adult mammalian cells. Nature 385, 810-813. 